\title{
The life and death of Private Harry Farr
}

\author{
Simon Wessely
}

J R Soc Med 2006;99:440-443

Last month the Defence Secretary Des Browne announced a formal pardon for Harry Farr, who had been shot at dawn for cowardice on 16 October 1916. The long-standing campaign for a pardon, not just for Harry Farr but for all those executed for military offences during the First World War, has been concluded. Most people will probably have been pleased by the result, and feel that justice has finally been done. Now that a pardon will be granted, it is timely to review what we know about the life and death of Harry Farr.

There is little dispute about the sequence of events on 17 September 1916 that led to the execution of Private Farr. Harry Farr was a member of 1st Battalion West Yorkshire Regiment, which was taking part in the battle of the Somme. That day his battalion was moving from their rear positions up to the front line itself. At $9.00 \mathrm{am}$ that morning Farr asked for permission to fall out, saying he was not well. He was sent to see the medical officer, who either found nothing wrong with him, or refused to see him because he had no physical injury - the Court Martial papers are unclear on this point. Later that night Farr was found still at the rear, and was again ordered to go the trenches. He refused, telling Regimental Sergeant Major Haking, that he 'could not stand it'. Then Hanking replied 'You are a fucking coward and you will go to the trenches. I give fuck all for my life and I give fuck all for yours and I'll get you fucking well shot'. At $11.00 \mathrm{pm}$ that night a final attempt was made to get Private Farr up to the front line, and he was escorted forward. A fracas broke out between Farr and his escorts, and this time they let him run away. The following morning he was arrested and charged with contravening section 4 (7) of the Army Act-showing cowardice in the face of the enemy.

The Field General Court Martial took place 2 weeks later. Four soldiers gave evidence against Farr, confirming the general sequence of events, which Farr did not deny. Farr was not represented by a so called 'prisoner's friend' (this was not unusual ${ }^{1}$ ), but spoke in his own defence. He was asked by the president of the court whether he had the opportunity to report sick between the night of the offence and now; Farr replied that he had indeed had the opportunity but had not done so. When asked why Farr

King's Centre for Military Health Research, Institute of Psychiatry, King's College London, London SE5 9RJ, UK.

E-mail: s.wessely@iop.kcl.ac.uk replied, almost certainly unwisely for his future, that this was because 'being away from the shell fire I felt better'. The Court then heard about his medical history and his disciplinary record, which, apart from a brief period of going absent without leave in 1914 had been exemplary. Private Farr had spent several months in a rear hospital in 1915 with a diagnosis of shell shock, had been treated by the medical officer with the same diagnosis in April 1916, and again for one day in July 1916. Unfortunately, the medical officer who had treated Farr was not able to give evidence: he had been severely wounded. Despite intense searching, we have found no other information about Farr's medical history; the records were almost certainly lost when the Public Records Office was bombed in 1940.

The Court Martial lasted less than an hour. For the military, it was probably an open and shut case. The evidence against Private Farr was overwhelming. He had absented himself from duty on several occasions, despite being told forcefully the consequence of his actions. The events took place 'in the face of the enemy'. He was found guilty, and sentenced to death.

Despite receiving the death sentence Harry could still have comforted himself that he was unlikely to be executed, since he would have known that most of those who received a capital sentence from a Court Martial were soon reprieved. Between August 1914 and October 1918 there were around 240000 Courts Martial, of which 3080 resulted in a death sentence. Of these 3080, $346(11 \%)$ were carried out, 2734 were not. ${ }^{1}$ Private Farr was charged with cowardice. There were 551 Courts Martial for cowardice that resulted in a guilty verdict, but only 18 (3.3\%) executions. No execution could take place until it had been confirmed by the Commander-in-Chief (France) Sir Douglas Haig, and in nine out of ten occasions he did not. Farr was one of the unlucky ones; and to understand why this was we need first to consider the military background to Farr's offence.

What was going through Haig's mind when he signed Private Farr's death warrant? To answer that we must be careful not to read history backwards. By 1916 there were large issues that preyed on the minds of the senior British commanders. It was not a foregone conclusion that the British Army would be able to continue to withstand the strain of the Western Front. Only a few months later the French Army would mutiny, and remain paralysed for most 
of 1917. The Italians collapsed at Caporetto, and the Russian armies disintegrated in the same year. In fact, the British Army did withstand the almost unimaginable strain, and in 1918 would win what many historians to be its finest feat of arms, but that was still to come.

Haig had reason to be worried. By 1916 most of the regular army, the 'Old Contemptibles' had gone. In their place came the citizen army, the Kitchener Army, followed by the conscripts of 1917. For regulars such as Haig these were viewed with suspicion. They were not lacking in patriotism or morale, but they were not proper soldiers. They had no professional military training, or previous service. No one knew how the mass citizen armies would withstand the new and terrible environment of industrialized warfare. Haig and his colleagues were constantly on the alert for signs of a reducing of morale, or a worsening of discipline, that might precede a catastrophic collapse or mutiny.

Haig, like all his colleagues, believed that the main reason that his men fought was because of their patriotism, sense of duty, leadership, and local esprit de corps. But if those were the carrots, there was also no dissention from the view that occasionally the stick was needed as well. The new army required a stern system of discipline much as applied to the pre war regulars if it was to endure. The regular army was expected to set the example - and Private Farr, as a regular, would be judged by those standards.

Yet even in the testing years of 1916 and 1917 it remained the case that, despite all the pressures, Haig still showed clemency to the vast majority of those sentenced to death for military offences. Why was Farr the exception? Part of the answer to that question lies in the exact circumstances of the fateful day when Farr refused RSM Haking's orders to go forward.

The Battle of the Somme had been renewed the day before, in what historians now call the battle of FlersCourcelette. The West Yorks were due to join this battle the following morning as part of 6th Division's assault against the notorious fortified German position known as the 'Quadrilateral'.

Farr was moving through what was known as 'Chimpanzee Valley', where his unit was forming up. It was a particularly unpleasant location because of the proximity of the British artillery laying down the barrage for the attack the following day (Corns, personal communication). It was those guns, not the German guns as some think, that so disturbed Harry. War diaries for that day report intense British artillery fire for much of the 16 September, and then again intense fire directed at the Quadrilateral in the evening of the 17 September.

It would have been common knowledge that the battalion was to go into action the following dawn: as indeed it did. And it would be common knowledge that this would be costly: as indeed it was. There were 150 casualties out of a battalion strength of 600 . So Private Farr's refusal to go to the trenches on the night of 17 September would have been interpreted by his comrades, NCOs and officers in the light of the forthcoming action. The four sergeants and privates who gave evidence against Farr all took part in the attack, and survived. And all would have had friends who did not.

It was a very bad night to break down. Usually soldiers facing a capital charge would have people to speak up for them, and give evidence as to their sound character, previous service and so on. Yet in Farr's case this kind of testimony is either absent or ambiguous. As the papers of the Field General Court Martial processed up the chain of command, being first reviewed by the legal section (who found no legal anomalies, and hence no grounds to quash the conviction), six different officers had the opportunity to add their comments. Farr's commanding officer was the first, and wrote:

'I cannot say what has destroyed this man's nerves, but he has proved himself on many occasions incapable of keeping his head in action and likely to cause a panic. Apart from his behaviour under fire, his conduct and character are very good.'

This was not very helpful, but it would have been the comments from General Cavan, GOC 4th division, that sealed Farr's fate:

"The charge of "cowardice" seems to be clearly proved and the Sgt Major's opinion of the man is definitely bad to say the least of it. The G.O.C. 6th Div. informs me that the men know the man is no good. I therefore recommend that the sentence be carried out.'

Nothing was said at the Court Martial about what had happened to the battalion in the hours after Farr's desertion, but nothing would have needed to have been said. Everyone knew. There were and are considerable difference in military honour and codes of behaviour between 'scrimshanking' — breaking the rules, stealing better provisions, avoiding onerous duties, missing out on parades and so on, and letting your mates down and leaving them in danger. The former is seen with approval by your comrades, if not the NCOs or officers, but the latter is not. ${ }^{2}$ It may have been for this reason that Farr's comrades were so reluctant to speak up for him, testimony which if present would normally have led to a reprieve. None was forthcoming for Farr-rather the opposite. And so Rawlinson, and then Haig, endorsed the sentence, and the last act of the tragedy took place at Carnoy at dawn on the 18 October 1916. 
But there is another factor which, to our modern mind, seems to sum up the insensitivity and injustice of Farr's fate. Prior to his refusal to join his comrades in the trenches ready for the attack on the Quadrilateral, Farr had on at least three occasions being hospitalized with a diagnosis of shell shock. Even his commanding officer admitted that Farr's 'nerves' had been destroyed. Surely, that should have led to a more compassionate verdict? Was Farr not suffering from what contemporary psychiatrists call post-traumatic stress disorder, which was the opinion of the modern psychiatrists who wrote in support of Gertrude Farr's plea for pardon for her father?

To understand why this did not happen, we need to think a little more about the concepts of psychological disorder that existed in 1916. In fact, shell shock is not just another name for post-traumatic stress disorder. Each disorder had different symptoms. We for example have shown that the 'flashback', characteristic of modern posttraumatic stress disorder, is absent from medical files of shell shock victims of the First World War; but this is not an important point. More importantly, it is not true to say, as many do, that the military and medical authorities were blind to the psychiatric consequences of war. The sheer scale of the psychiatric casualties meant that this was impossible. But what was different was their understanding of why men broke down in battle, or more particularly, why they did not get better. ${ }^{3}$

By 1916 it was accepted that many men could break down if pushed long and hard enough. But if a person was fundamentally 'sound', provided that he was managed correctly — and, in particular, not given a medical label nor sent to a rear hospital for a prolonged period of time - this condition ought to be short lived. But if a person did not recover, despite good management, then the war was only the trigger, the real causes of the prolonged breakdown lying elsewhere. The true cause was either inheritance, some form of constitutional weakness, or genetics as we would say now; alternatively, if the doctor was more aware of Freud and his theories, then it was the soldier's early life and upbringing. Either way one's card was marked long before the person joined up. A short-term breakdown could be the result of the war, but the longer the condition persisted, the more likely it was to be the result of a defect in character. The officers and medical officers of the First World War were Victorians and Edwardians, to whom character mattered, and mattered immensely.

At the end of the War a Royal Commission was formed to try and understand exactly what shell shock was, and why had it become such a problem. Rather than accepting that psychiatric breakdown was the inevitable result of modern war, and that 'every man has his breaking point' (a conclusion that was reached only after the Second World
Gort VC, who told them shell shock was a regrettable weakness, and was not found in good units. The Commission concluded that good soldiers, properly led, with good morale and good training, should not break down. ${ }^{5}$ All their witnesses also told them that shell shock was contagious and hence a threat to fighting spirit- so Farr's commanding officer comments that he was 'liable to cause a panic' awakened every suspicion about shell shock in the military mind, and did not help him.

So how could one separate out those who refused to fight for legitimate reasons, and deserved sympathy, from those who refused to fight because they were cowards? It was not easy. What does modern psychiatry say? Nothing. I searched in vain every contemporary textbook of psychiatry that the Maudsley Hospital possesses for any mention of the word cowardice, but it is entirely absent. We are never called on to even consider the question, thankfully. But back in 1916 they did not have that luxury, and the distinction was, literally for Private Farr, a matter of life and death. Eventually the best guidance that the Shell Shock Commission could give was that if a man had previously shown courage, then he should not be considered a coward. ${ }^{6}$ A man who had 'done his bit' should, and indeed did, receive more sympathy and understanding than one who had not. It was a moral matter. Even in the modern army it helps to have 'earned' your breakdown.

So the label of shell shock, which to our modern mind is synonymous with psychiatric disorder, and should automatically have meant mercy for Farr, was more ambiguous to the people of 1916. It was already falling into disrepute, and was being increased seen on both sides of the trenches as a convenient medical label for people to avoid their duties, and would be banned completely as a diagnosis in 1917. ${ }^{7,8}$ It was not, however, the case that mental illness could never be a defence to a capital charge. Lt Sidney Stuart Hume, for example, shot an orderly in 1918, but was found insane by the same rules that still apply today, and was committed to Broadmoor, where he remained until 1976 (Barham P, personal communication). But Harry Farr was not insane. Others were sometimes reprieved because they had obvious signs of other mental disorders - but at his trial Farr was found to be in a 'satisfactory' mental condition by the medical officer, whatever that meant. More importantly, Farr himself had unwisely told the president of the Court Martial that away from the guns he was now better. This would have been seen as incompatible with a total nervous collapse. Medical officers did frequently send soldiers back down the line for nervous problems - it had happened to Farr on three previous occasions - but not the night before a big attack. Only 2 months before Farr's fateful day Lt Kirkwood RAMC, a medical officer with the 11th Border Regiment, had certified that one-third of his battalion were unfit to take 
part in a planned trench raid because they were suffering from 'some degree of shell shock'. He was relieved of his post the following morning. ${ }^{9}$ When the needs of the military conflicted with the needs of the individual, there was no doubt on whose side the medical officer was meant to be.

We can be sure that on the night of 17 September 1916 Harry Farr was in a state of intense fear. There were no psychiatrists available on the Western Front (psychiatrists were mainly asylum doctors anyway who looked after the insane), but if a modern psychiatrist had made the journey back in time to interview Farr, it is probable the diagnosis would be of some form of anxiety, phobic or post-traumatic stress disorder (the diagnoses are not exclusive). A phobic disorder is when a person experiences severe irrational disabling symptoms out of proportion to any actual risk. There is no rational reason to be crippled with anxiety when confronted with a spider, nor to have panic attacks inside a supermarket. But there was nothing irrational about Farr's fears that night-indeed, one might argue that refusing to go 'over the top' was the most rational response to the situation: a veritable Catch 22. And that night Farr would not have been alone in experiencing intense fearthere were probably few around him who did not feel something similar as they faced the prospect of attacking the notorious Quadrilateral the following morning. What the Court Martial had to consider was that Farr did not control his fears, whilst his comrades did.

Modern psychiatrists like me can count themselves lucky that we will never be placed in the situation of judging Harry Farr's behaviour and those of his comrades. Instead, those who did have the task of judging Farr's actions were faced with a dilemma. They wished to, and usually did, show concern for the welfare of the individual soldier. But they also wanted to promote order and discipline, and to ensure that soldiers continued to risk their lives in combat. They believed that this required sanctions up to the supreme penalty for those who tried to avoid those duties. It was always a balance between showing mercy and enforcing discipline. Although the usual outcome was the former, for Private Farr they choose the latter.

Speaking now personally, I wish that they had not. It seems very probable that Farr was suffering from a psychiatric disorder, even if we do not know which one. We are more sympathetic towards psychiatric breakdown now, although perhaps not as much as we think we are. Anyway, irrespective of Private Farr's mental state, I remain utterly opposed to the death penalty for any reason. But that was not the view in 1916, either in the military or in civil society. Our social climate has changed, both towards the death penalty and towards psychiatric illness, and thank goodness for that.
But greater compassion is not necessarily the same as greater understanding. We should be careful of viewing the past through our modern sensibilities. The best we can do is to try and understand the actions of all the men of 1916, including Private Farr and those who judged him, and not to make apologies for either. Nor should we succumb to the temptation to rewrite history to make ourselves feel more comfortable about the past.

In his recent social history of the British soldier in the First World War Richard Holmes ${ }^{10}$ probably got it about right when he gave his thoughts on the subject of military executions in the First World War:

' . . the most that one can say is that the overwhelming majority were justly convicted by the law as it then stood it was indeed a hard law but it was, in general, fairly applied. But like so much else about the war, the issue divides head from heart and if my head applauds the logic of capital sentences, they still break my heart'.

Acknowledgments I wish to thank Corporate Memory at the Ministry of Defence for obtaining the relevant War Diaries. I am also grateful to Cathryn Corns, Ben Shephard, Edgar Jones, Peter Barham, Paul Lerner and Tim Finnegan for their comments.

Competing interests Simon Wessely is Co-Director of the King's Centre for Military Health Research, part of King's College London. He is also Honorary Civilian Advisor in Psychiatry for the British Army.

\section{REFERENCES}

1 Corns C, Hughes-Wilson J. Blindfold and Alone: British Military Executions in the Great War. London: Cassell, 2001

2 Palmer I. The emotion that dare not speak its name? Br Army Rev 2003; 132:31-7

3 Jones E, Wessely S. From Shell Shock to PTSD: A History of Military Psychiatry. London: Psychology Press, 2005

4 Jones E, Wessely S. The impact of total war on the practice of psychiatry. In: Chickering R, Forster S, eds. Shadows of Total War: 1919-1939. Cambridge: Cambridge University Press, 2001:129-48

5 Bogacz T. War neurosis and cultural change in England, 1914-1922: the work of the war office committee of enquiry into shellshock. J Contemp Hist 1989;24:227-56

6 Report of the War Office Committee of Enquiry into 'Shell-Shock'. London: HMSO, 1922

7 Leese P. Shell Shock: Traumatic Neurosis and the British Soldiers of the First World War. Basingstoke: Palgrave, 2002

8 Lerner P. Hysterical Men: War, Psychiatry and the Politics of Trauma in Germany, 1890-1930.New York: Cornell University Press, 2003

9 Shephard B. A War of Nerves, Soldiers and Psychiatrists 1914-1994. London: Jonathan Cape, 2000

10 Holmes R. Tommy: The British Soldier on the Western Front, 1914-1918. London: Harper Perennial, 2005 